\title{
Serum leptin concentrations during the menstrual cycle in normal-weight women: effects of an oral triphasic estrogen-progestin medication
}

\author{
Franca Cella, Giulio Giordano and Renzo Cordera \\ Department of Endocrinology and Metabolism, Dipartimento di Scienze Endocrinologiche e Metaboliche (DiSEM), University of Genova, \\ Viale Benedetto XV-6, 16132 Genova, Italy \\ (Correspondence should be addressed to R Cordera; E-mail: record@unige.it)
}

\begin{abstract}
Objective: To investigate in normal-weight premenopausal women the relationship between circulating leptin and serum gonadotropins and gonadal steroids, during both spontaneous and pharmacologically induced menstrual cycles.

Design: Clinical longitudinal study.

Methods: Two groups of age-matched, normal-weight premenopausal volunteer women (groups I and II) were enrolled in this study. Women in group I were free of any hormonal treatment, while women in group II were taking a triphasic estrogen-progestin contraceptive preparation. Blood samples were collected daily in both groups after an overnight fast throughout a complete menstrual cycle.

Results: In the spontaneously cycling women, serum leptin concentration positively correlated with estradiol $(P<0.03)$ and progesterone $(P<0.05)$ and was higher in the luteal than in the follicular phase $(P<0.05)$. However, a significant $(P<0.03)$ short-lasting increase in circulating leptin was present in the late follicular phase of all subjects. In the women using hormonal contraception serum leptin remained unchanged throughout the cycle, along with constantly low values of circulating luteinizing hormone and follicle-stimulating hormone.

Conclusions: In normal-weight premenopausal women serum leptin concentrations differ during the menstrual cycle in line with changes in gonadotropin and gonadal steroid concentrations, increasing in the luteal phase of the cycle after a peri-ovulatory peak. These findings suggest a permissive role for leptin with regard to the functioning of the corpus luteum.
\end{abstract}

European Journal of Endocrinology 142 174-178

\section{Introduction}

Leptin, the hormone encoded by the $o b$ gene (1), is a peripheral signal of nutritional status to the central nervous system. In animals, intracerebroventricular administration of leptin causes weight loss by inhibiting food intake and increasing energy expenditure, oxygen consumption and thermogenesis (2,3). Exogenous administration of leptin affects not only nutritional homeostasis but also reproductive events, accelerating the onset of puberty in sexually immature animals $(4,5)$, correcting the sterility defect in homozygous $o b / o b$ mice $(6,7)$, and reversing starvation-induced hypogonadism in mice (4). On the other hand, administration of leptin antiserum to adult female rats leads to a marked decrease in luteinizing hormone (LH) pulsatility (8). In humans, several observations suggest that gonadal steroids might modulate leptin expression: (a) in women circulating leptin is higher than in men, even when adjusted for body mass index (BMI) and absolute fat mass $(9,10)$; (b) among women serum leptin is higher in premenopausal than in menopausal subjects (11-13); (c) most authors agree that in cycling women circulating leptin is higher in the luteal phase than in the follicular phase (13-15); (d) plasma leptin concentrations increase at the onset of puberty $(16,17)$; (e) both long and short isoforms of leptin receptors have been demonstrated in the human ovary (18).

Data gained from experiments with rats demonstrate that leptin can affect the hypothalamic-pituitarygonadal axis by acting directly on the hypothalamus, the pituitary gland, and the gonads. As for the hypothalamus, leptin is able to increase luteinizing hormonereleasing hormone (LHRH) release from medial basal hypothalamic explants (19); in the pituitary, leptin stimulates LH and follicle-stimulating hormone (FSH) release (19); in the ovary leptin impairs the synergistic action of insulin-like growth factor-I (IGF-I) on FSHstimulated estradiol-17 $\beta$ synthesis by granulosa cells (20). 
The aim of this study was to evaluate how serum leptin concentrations vary during the menstrual cycle in healthy premenopausal women and healthy premenopausal women taking oral contraceptives. In particular, we attempted to investigate possible changes in circulating leptin around the time of ovulation.

\section{Subjects and methods}

Eight normal-weight regularly cycling volunteer women (group I) (age: $29.7 \pm 4.8$ years (mean \pm s.D.); BMI: $22.0 \pm 1.3 \mathrm{~kg} / \mathrm{m}^{2}$ ) and eight age- and BMI-matched volunteer women taking an oral contraceptive preparation (group II) (age: $28.8 \pm 3.7$ years; BMI: $22.3 \pm$ $1.1 \mathrm{~kg} / \mathrm{m}^{2}$ ) were enrolled in the study. As we did not intend to evaluate the correlations between the two groups, the number of subjects enrolled in each group was limited by the availability of suitable volunteers: in fact, as calculated by GraphPad StatMate, the power of the study was only $20 \%$ and statistical comparisons between the two groups will not be considered. The oral contraceptive was a triphasic preparation containing 0.03, 0.04 and $0.03 \mathrm{mg}$ ethynilestradiol and 0.05, 0.07 and $0.1 \mathrm{mg}$ gestoden (Triminulet, Wyeth, Maidenhead, UK), and it had been taken by the subjects for at least 3 months. None of the volunteers suffered from chronic or endocrinologic disease, or was on any medication known to affect the metabolic or endocrinologic parameters, except the oral contraceptive when indicated. All participants gave written informed consent to the trial and the study protocol was approved by the University of Genova (DiSEM) Ethics Review Committee.

Since the ovulatory peak of serum LH and FSH is a rapid, transient event and since it cannot be predicted if and when similarly rapid variations in serum leptin will occur, blood samples for measurement of LH, FSH, estradiol $\left(\mathrm{E}_{2}\right)$, progesterone $(\mathrm{Pg})$, and leptin levels were drawn daily throughout a complete menstrual cycle, from the first day of bleeding of the cycle to the first day of bleeding of the next cycle. All blood samples were taken by venipuncture between $0730 \mathrm{~h}$ and $0830 \mathrm{~h}$ after an overnight fast.

Throughout the study all subjects kept a food diary to ascertain whether any variation in caloric intake correlated with variations in serum leptin.

Serum leptin concentrations were determined simultaneously for each subject using a commercially available radioimmunoassay kit (DRG Instruments
GmbH, Marburg). The interassay coefficient of variation (c.v.) for the quality control was $5.7 \%$, the intra-assay c.v. was $3.7 \%$. Serum LH and FSH were measured by immunoenzymometric assay kits (IEMA Well, Radim, Angleur), while serum $\mathrm{E}_{2}$ and $\mathrm{Pg}$ were measured by chemiluminescent enzyme immunoassay kits (Immulite, DPC, Los Angeles, CA, USA).

Statistical analysis was performed by one-way ANOVA for repeated measurements, by linear regression analysis, and by Student's paired $t$-test (level of significance: $P<0.05)$. All data are expressed as means \pm S.D.

\section{Results}

In the spontaneously cycling women of group I, ovulation was demonstrated by the rise in Pg concentration to over $3 \mathrm{ng} / \mathrm{ml}$, with LH and FSH concentrations peaking at mid-cycle, and $\mathrm{E}_{2}$ concentration increasing in the luteal phase of the cycle (Table 1). Though leptin concentration showed considerable variability throughout the menstrual cycle, there was positive correlation with $\mathrm{E}_{2}(P<0.03)$ and Pg concentrations $(P<0.05)$, increasing significantly $(P<0.05)$ in the luteal phase compared with the follicular phase; there was no correlation with LH and FSH concentrations. The mean concentration of leptin in the follicular phase was $6.4 \pm 2.9 \mathrm{ng} / \mathrm{ml}$, while in the luteal phase it was $10.2 \pm 4.5 \mathrm{ng} / \mathrm{ml}$. When calculated as area under the curve (AUC) of concentration vs time, the mean concentration of leptin in the follicular phase was $83.8 \pm 3.9 \mathrm{ng} /$ day and in the luteal phase was $104.5 \pm$ $3.3 \mathrm{ng} /$ day $(P<0.008)$. Body weight showed no significant variation during the menstrual cycle, nor did the caloric intake, which in three subjects was slightly higher by the beginning of the menstrual bleeding. Consequently, the correlation index between serum leptin concentration and BMI was different in the two menstrual phases, being more significant in the luteal phase (correlation coefficient, $r^{2}=0.718 ; P=0.008$ ) than in the follicular phase $\left(r^{2}=0.675 ; P=0.01\right)$. However, in all subjects a surge in serum leptin concentration lasting 1-2 days could be identified in the late follicular phase, between days 8 and 14, on varying days among the subjects with no fixed correlation to the day of ovulation. The magnitude of this surge (mean leptin concentration: $12.3 \pm 6.1 \mathrm{ng} / \mathrm{ml}$ ) was similar to or even greater than the luteal increase in circulating leptin,

Table 1 Mean serum concentrations of gonadotrophins and gonadal steroids during different phases of the menstrual cycle in the spontaneously cycling women (group I). All data are expressed as means \pm S.D.

\begin{tabular}{lrccr}
\hline Day of the cycle & LH $(\mathrm{mlU} / \mathrm{ml})$ & FSH $(\mathrm{mlU} / \mathrm{ml})$ & $\mathbf{E}_{2}(\mathrm{pg} / \mathrm{ml})$ & $\mathrm{Pg}(\mathrm{ng} / \mathrm{ml})$ \\
\hline 7 & $1.13 \pm 1.3$ & $5.67 \pm 2.6$ & $75.9 \pm 42.1$ & $0.74 \pm 0.3$ \\
14 & $19.64 \pm 8.2$ & $14.26 \pm 6.5$ & $216.1 \pm 105.3$ & $1.35 \pm 0.5$ \\
21 & $0.96 \pm 1.1$ & $3.14 \pm 1.1$ & $69.3 \pm 30.6$ & $16.04 \pm 8.2$ \\
\hline
\end{tabular}



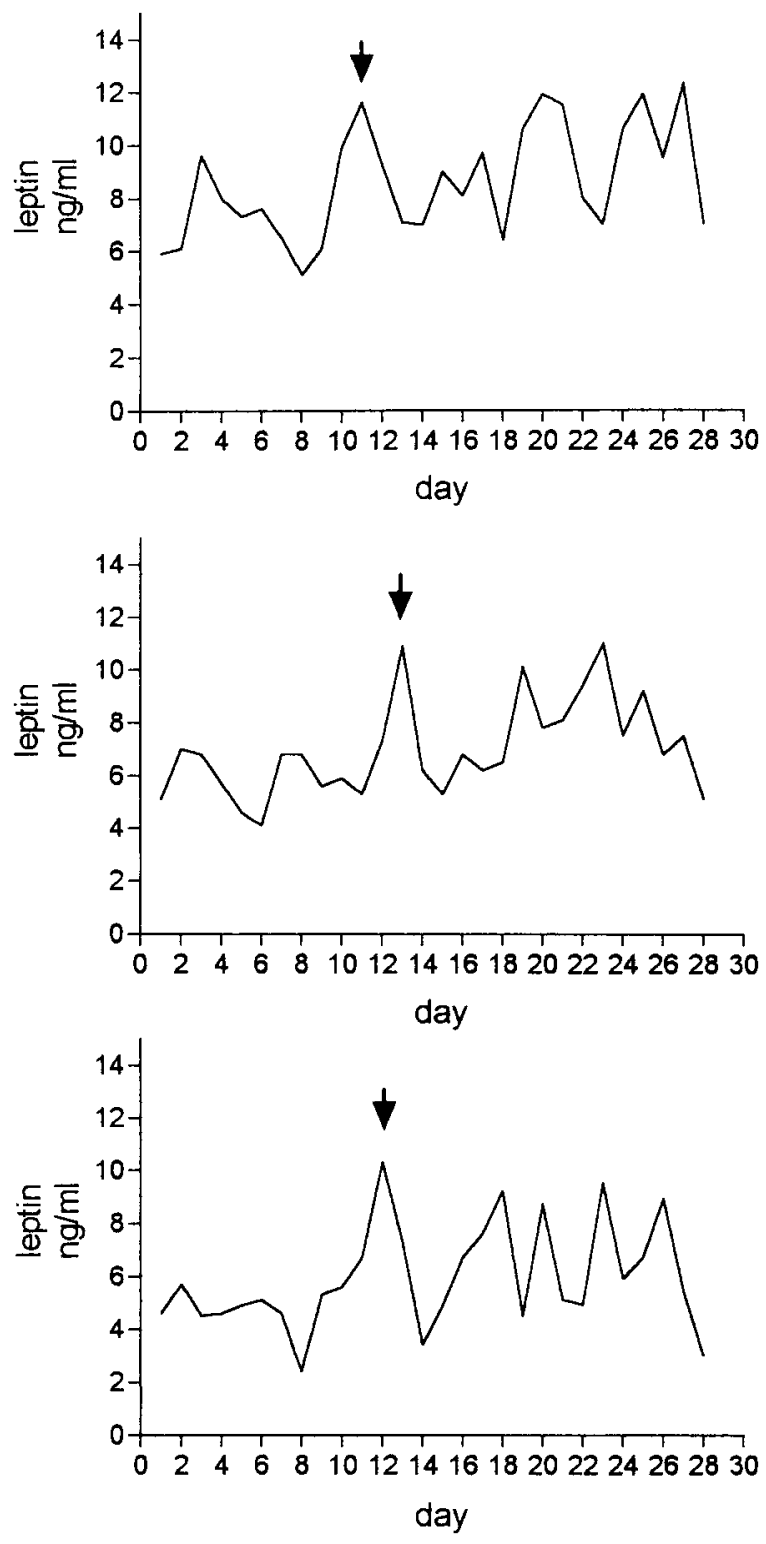

Figure 1 Variations in serum leptin concentration during the menstrual cycle in three of the eight spontaneously cycling women of group I. and was significantly different from the leptin concentrations on the day before and the day after the peak $(P<0.03)$ (Fig. 1).

In the women receiving oral contraceptives (group II), serum leptin remained unchanged throughout the cycle, the mean value $(7.1+0.3 \mathrm{ng} / \mathrm{ml})$ not differing significantly from that in group I $(8.3+2.7 \mathrm{ng} / \mathrm{ml})$. Serum LH and FSH concentrations remained low during the cycle, as did the concentrations of $\mathrm{E}_{2}$ and $\mathrm{Pg}$ as detected by the enzyme immunoassay (Table 2). Although the specificity of our immunoassay did not allow us to determine precisely the blood values of the exogenous estrogen and progestin, it seems reasonable to assume that the three different doses of ethynilestradiol and gestoden resulted in different effective values of circulating hormones.

\section{Discussion}

Our data suggest that: (a) in regularly cycling normalweight women serum leptin concentration varies significantly during the menstrual cycle, increasing $(P<0.05)$ in the luteal phase of the cycle and correlating with serum $\mathrm{E}_{2} \quad(P<0.03)$ and $\mathrm{Pg}(P<$ $0.05)$ concentrations, and (b) a significant $(P<0.03)$ peak of circulating leptin occurs in the late-follicular/ pre-ovulatory phase of the cycle.

These observations confirm previous findings of an increase in serum leptin during the luteal phase of the cycle (13-15), but also highlight a potential role for leptin with regard to ovulation, as an early increase in circulating leptin occurs before or at the same time as the mid-cycle surge in LH and FSH concentration. Moreover, our study is also in accordance with a recent paper showing that estrogen-progestin therapy does not affect serum leptin concentrations (21). On the other hand, our data seem to contradict the report by Teirmaa et al. (22), who found a correlation between leptin and LH concentrations during the cycle.

The regulatory loop by which leptin concentrations vary during the menstrual cycle is not clear. Apparently, in this mechanism peripheral signals by the adipocytes do not play a major role, as no significant changes in fat mass or caloric intake were evident in our subjects. In fact, a recent paper by Paolisso et al. (23) has shown a lack of correlation between changes in circulating leptin values and food intake during the menstrual cycle.

Table 2 Mean serum concentrations of gonadotrophins and gonadal steroids during different phases of the menstrual cycle in women taking the oral contraception preparation (group II). All data are expressed as means \pm S.D.

\begin{tabular}{lcccc}
\hline Day of the cycle & LH $(\mathrm{mlU} / \mathrm{ml})$ & $\mathbf{F S H}(\mathrm{mlU} / \mathrm{ml})$ & $\mathbf{E}_{\mathbf{2}}(\mathrm{pg} / \mathrm{ml})$ & $\mathbf{P g}(\mathrm{ng} / \mathrm{ml})$ \\
\hline 7 & $0.44 \pm 0.36$ & $1.73 \pm 1.54$ & $13.45 \pm 7.23$ & $0.51 \pm 0.09$ \\
14 & $0.56 \pm 0.45$ & $2.01 \pm 1.99$ & $18.63 \pm 9.25$ & $0.55 \pm 0.11$ \\
21 & $0.61 \pm 0.53$ & $1.89 \pm 1.74$ & $16.76 \pm 8.92$ & $0.69 \pm 0.17$
\end{tabular}


Moreover, since in our study exogenous administration of different doses of estrogen and progestin did not influence serum leptin, it seems plausible that with regard to the reproductive system leptin mainly acts through or is under the central control of the hypothalamic-pituitary axis, possibly with the mediation of neuropeptide Y. However, the presence of leptin receptors in the gonads (18) may represent a direct effect of leptin on the ovaries. As ovarian production of leptin has also been demonstrated (24), it cannot be excluded that in the luteal phase of the cycle more leptin is released by the ovarian follicles which develop, may be through a positive feedback mechanism. In fact, the pre-ovulatory surge of estrogen might prime the increase of circulating leptin, which in turn could stimulate the gonads to produce more leptin together with increasing titres of progesterone. However, it is not possible from our data to draw any definitive conclusion. In contrast to this, Licinio et al. (25) proposed that leptin might regulate the minute-tominute oscillations in the levels of LH and estradiol, and that the nocturnal rise in leptin may determine the change in nocturnal LH profile in the mid-to-late follicular phase that precedes ovulation. A synchronized copulsatility between LH and leptin has further been confirmed in both normal women and patients with polycystic ovary syndrome (PCOS) by Sir-Petermann et al. (26). Most likely the role of leptin in the menstrual cycle is the result of an interaction between both central and peripheral signals of the hypothalamic-pituitarygonadal axis.

Although the physiologic role of the changes in plasma leptin during the menstrual cycle is unclear, it appears evident that a minimum threshold of circulating leptin is necessary for a regular ovulatory function, as it is well known that amenorrhea occurs in conditions of low serum leptin, such as in highly trained women or in women with anorexia nervosa (27).

Thus, leptin clearly appears to be linked to the reproductive system, probably coupling information about the adequacy of body energy homeostasis to the potential occurrence of a pregnancy, indicating the availability of nutritional resources to successful reproduction.

\section{References}

1 Zhang Y, Proenca R, Maffei M, Barone M, Leopold L \& Friedman JM. Positional cloning of the mouse obese gene and its human homologue. Nature 1994372 425-432.

2 Hwa JJ, Ghibaudi L, Compton D, Fawzi AB \& Strader CD. Intracerebroventricular injection of leptin increases thermogenesis and mobilizes fat metabolism in ob/ob mice. Hormone and Metabolic Research 199628 659-663.

3 Hwa JJ, Fawzi AB, Graziano MP, Ghibaudi L, Williams P, Van Heek $\mathrm{M}$ et al. Leptin increases energy expenditure and selectively promotes fat metabolism in ob/ob mice. American Journal of Physiology 1997272 R1204-R1209.
4 Ahima RS, Prabakaran D, Mantzoros C, Qu D, Lowell B, MaratosFlier $\mathrm{E}$ et al. Role of leptin in the neuroendocrine response to fasting. Nature 1996382 250-252.

5 Chehab FF, Mounzih K, Lu RH \& Lim ME. Early onset of reproductive function in normal female mice treated with leptin. Science $199727588-90$.

6 Chehab FF, Lim ME \& Lu RH. Correction of the sterility defect in homozygous obese female mice by treatment with human recombinant leptin. Nature Genetics 199612 318-320.

7 Mounzih K, Lu R \& Chehab FF. Leptin treatment rescues the sterility of genetically obese $o b / o b$ males. Endocrinology 1997138 1190-1193.

8 Carro E, Pinilla L, Seoane LM, Considine RV, Aguilar E, Casanueva FF et al. Influence of endogenous leptin tone on the estrous cycle and luteinizing hormone pulsatility in female rats. Neuroendocrinology 199766 375-377.

9 Ostlund REJ, Yang JW, Klein S \& Gingerich R. Relation between plasma leptin concentration and body fat, gender, diet, age, and metabolic covariates. Journal of Clinical Endocrinology and Metabolism 199681 3909-3913.

10 Saad MF, Damani S, Gingerich RL, Riad-Gabriel MG, Khan A, Boyadjian R et al. Sexual dimorphism in plasma leptin concentration. Journal of Clinical Endocrinology and Metabolism 199782 579-584.

11 Rosenbaum M, Nicolson M, Hirsch J, Heymsfield SB, Gallagher D, Chu F et al. Effects of gender, body composition, and menopause on plasma concentrations of leptin. Journal of Clinical Endocrinology and Metabolism 199681 3424-3427.

12 Shimizu H, Shimomura Y, Nakanishi Y, Futawatari T, Ohtani K, Sato $\mathrm{N}$ et al. Estrogen increases in vivo leptin production in rats and human subjects. Journal of Endocrinology $1997154285-$ 292.

13 Riad-Gabriel MG, Jinagouda SD, Sharma A, Boyadjian R \& Saad MF. Changes in plasma leptin during the menstrual cycle. European Journal of Endocrinology 1998139 528-531.

14 Lukaszuk K, Liss J, Kusiak E \& Wjcikowski CZ. Serum leptin concentration increase during luteal phase in healthy premenopausal women. Hormone and Metabolic Research $199830172-$ 174.

15 Hardie L, Trayhurn P, Abramovich D \& Fowler P. Circulating leptin in women: a longitudinal study in the menstrual cycle and during pregnancy. Clinical Endocrinology 199747 101-106.

16 Hassink SG, Sheslow DV, de Lancey E, Opentanova I, Considine RV \& Caro JF. Serum leptin in children with obesity: relationship to gender and development. Pediatrics 199698 201-203.

17 Mantzoros CS, Flier JS \& Rogol AD. A longitudinal assessment of hormonal and physical alterations during normal puberty in boys. V. Rising leptin levels may signal the onset of puberty. Journal of Clinical Endocrinology and Metabolism 199782 10661070.

18 Karlsson C, Lindell K, Svensson E, Bergh C, Lind P, Billig H et al. Expression of functional leptin receptors in the human ovary. Journal of Clinical Endocrinology and Metabolism 199782 41444148.

19 Yu WH, Kimura M, Walczewska A, Karanth S \& McCann SM. Role of leptin in hypothalamic-pituitary function. Proceedings of the National Academy of Sciences of the USA 199794 1023-1028.

20 Zachow RJ \& Magoffin DA. Direct intraovarian effects of leptin: Impairment of the synergistic action of insulin-like growth factorI on follicle-stimulating hormone-dependent estradiol-17 $\beta$ production by rat ovarian granulosa cells. Endocrinology 1997138 847-850.

21 Castracane VD, Kraemer RR, Franken MA, Kraemer GR \& Gimpel T. Serum leptin concentration in women: effect of age, obesity, and estrogen administration. Fertility and Sterility $199870472-$ 477.

22 Teirmaa T, Luukkaa V, Rouru J, Koulu M \& Huupponen R. Correlation between circulating leptin and luteinizing hormone during the menstrual cycle in normal-weight women. European Journal of Endocrinology 1998139 190-194. 
23 Paolisso G, Rizzo MR, Mazziotti G, Rotondi M, Tagliamonte MR, Varricchio $\mathrm{G}$ et al. Lack of association between changes in plasma leptin concentration and in food intake during the menstrual cycle. European Journal of Clinical Investigation 1999 $29490-495$.

24 Cioffi JA, Shafer AW, Zupancic TJ, Smith-Gbur J, Mikhail A, Platika $\mathrm{D}$ et al. Novel B219/OB receptor isoforms: possible role of leptin in hematopoiesis and reproduction. Nature Medicine 19962 585589.

25 Licinio J, Negrao AB, Mantzoros C, Kaklamani V, Wong M-L, Bongiorno PB et al. Synchronicity of frequently sampled, 24-h concentrations of circulating leptin, luteinizing hormone, and estradiol in healthy women. Proceedings of the National Academy of Sciences of the USA 199895 2541-2546.
26 Sir-Petermann T, Piwonka V, Perez F, Maliqueo M, Recabarren SE \& Wildt L. Are circulating leptin and luteinizing hormone synchronized in patients with polycystic ovary syndrome? Human Reproduction 199914 1435-1439.

27 Grinspoon S, Gulick T, Askari H, Landt M, Lee K, Anderson E et al. Serum leptin levels in women with anorexia nervosa. Journal of Clinical Endocrinology and Metabolism 199681 38613863.

Received 8 August 1999

Accepted 2 November 1999 